\title{
Saving Energy by Replacing IM with BLDC MOTOR in Fan Application
}

\author{
Loreta Nakuçi, Aida Spahiu
}

\begin{abstract}
Electrical drives with induction motors have been dominant in industry, residency and in automotive sector. So far the using of induction motor in these sectors has been a good choice because of its reliability, long life, simple structure, stability, etc. Technological progress in magnetic material technology, power electronics, integrated circuits and microcontrollers have created the conditions to design new types of the motors such as brushless direct current (BLDC) motors. BLDC motor possesses many advantages comparing with induction motor also DC motor. The using of intelligent control methods improves its performance. These reasons bring to an increasing of the application of this motor in many sectors. The paper aims to show a way of increasing the efficiency of electrical drives through replacing the induction motor with the BLDC motor (BrushLess Direct Current motor). In the paper is compared indirectly the efficiency of a three-phase brushless DC motor with single phase induction motor used in fan application. The analysis is specifically related to low power fan applications. Based on the experimental results presented in the paper is clearly noticed that BLDC motors used in fan application can increase efficiency and bring energy saving up to $35 \%$ compared to three-phase induction motors.
\end{abstract}

Index Terms—Brushless Direct Current Motor; Efficiency; Induction Motor; Losses.

\section{INTRODUCTION}

The creation of the legal framework for improving the electrical energy efficiency, increasing the security of energy supply, minimizing the negative impact on the environment it is the goal of the Albania government. The Law of Energy Efficiency 124/2015 and The Second and Third National Energy Efficiency Action Plan of Albania (NEEAP), approved on December 2017, help in this direction. There are many ways to arrive the improvement of the energy efficiency in Albania as they are described in NEEAP 2017.They are planned to achieve the indicative targets in the year 2020 [14].

NEEAP is focused on improving energy efficiency in all sectors. The values of the electrical energy saving within each sector are shown in the Table I. [14]. It looks clear from the indicative target that the residential, industry sectors have in important role in energy savings. Knowing that electric motors are used in many applications from appliances to power tools using energy efficient motor in such applications will bring potential energy savings in these sectors. The residential sector in 2013 consumed $60 \%$ of electricity in Albania and the consumption will be increased with $2.2 \%$ in every year until 2030 [14]. The

Published on August 10, 2018.

L. Nakuçi, Harry Fultz Institute,Tirana, Albania. loreta.nakuci@gmail.com

A. Spahiu, Polytechnic University, Tirana, Albania.aida_spahiu@yahoo.com paper aims to show that using energy efficiency electrical drives in residential applications can give their contribution in reducing of energy consumption.

TABLE I: ENERGY SAVING TARGET BY SECTOR [14]

\begin{tabular}{lcc}
\hline \hline Sector & $\begin{array}{c}\text { Energy Savings } \\
\text { in 2018 (ktoe) }\end{array}$ & $\begin{array}{c}\text { Energy } \\
\text { Savings up to } \\
\mathbf{2 0 2 0} \text { (ktoe) }\end{array}$ \\
\hline Residential & 10,6 & 37,43 \\
Services & 6,27 & 16 \\
Industry & 3,7 & 6,9 \\
Transport & 14,2 & 49,49 \\
Agriculture & 3,7 & 13,9 \\
Total Saving Potential & 38,5 & 123,7 \\
Total Saving Potential $(\mathrm{GWh})$ & 447,8 & 1438,5 \\
\hline \hline
\end{tabular}

The paper is focused in using of BLDC (Brushless Direct Current) motor instead of induction motor in fan application. A significant amount of motor applications are found in the form of fan applications such as bathroom exhaust fans, kitchen hood exhaust fans, appliance cooling fans, dryer exhaust fans, desk fans, inline fans, axial fans, attic ventilator fans, roof ventilation fans, radon fans, etc. Typical ventilation fans vary from $30 \mathrm{~W}$ to $80 \mathrm{~W}$ for residential applications. Types of the motors used in the fan applications are brushed DC motors, single-phase AC induction motors, shaded-pole induction motors, three-phase induction motors etc. [6].

This paper specifically relates low- power fan applications that include ventilation fans. The selection criteria of the motor includes efficiency, system cost, power quality, mechanical vibration, torque ripple, product life etc.

Historically, one-phase induction motors are commonly used in low power applications. But the production of permanent magnets with a higher energy product has enabled the production of a torque exceeding the torque value of a phase induction motor of the same size. These developments in magnet technology and 'enabling technology' in power semiconductors and integrated circuit lead to the using of non-classical motors such as brushless direct current motors (BLDC) and steppers in variable speed applications as fan application is [1]. After using the permanent magnet motors in the industry and in the transportation sectors, now it is transitioning even in the residential and commercial sectors, especially for the higher efficiency, cost effectiveness, reduced noise and the ability to reach higher rotational speeds [2].

There are two main ways to improve energy efficiency in fan application: using energy efficient motor, using variable speed drives to control fan flow [2]. The paper proposes as an effective way to reduce energy consumption the replacement of induction motor with BLDC motor in fan application. The substitution of the AC motors with BLDC 
motors has advantages as higher efficiency, smaller volume, lower weight which are especially important in the variable speed applications. Moreover, the request for long life and no maintenances, leads us to use the BLDC motors instead of DC motor.

\section{New Efficiency Classes of Induction Motors}

Alternative current induction motors are mass-produced by many manufacturers around the globe and sold in standard catalogue types and sizes because they are cheap and cost-effective during converting the electrical energy into rotational mechanical energy. They are effective to drive pumps, fans, compressors etc. at fixed speed. An induction motor to a general-purpose drive is considered to be power effective if it is increased power factor and reliability there are decreased capital and operation expenses and technical maintenance including. So the induction motor results as the most economic one which is common in design, simple and has a low cost at high sufficient reliability.

With the "efficiency" is meant how efficiently an electric motor provides the mechanical energy through transforming electrical energy. In many countries around the world was developed Energy efficiency standards which were very different from the European system. That was the reason for the European motor manufacturers in CEMEP, to develop an energy efficiency standard for the International Electro Technical Commission (IEC). The objective was to have a common international standard that replaces all the different national systems.

The new international standard, IEC 60034-30:2008, defines efficiency classes IE1, IE2 and IE3 for three-phase motors. This ensures a common international basis for the design and classification of motors as well as for national legislative activities.

At the same time, the IEC developed improved methods for determining the efficiency of these motors. The efficiency class system specified under IEC 60034-30 is valid for low voltage three-phase cage induction motors [6].

Energy Efficiency Motor (EEM) is manufactured using the same frame as a standard motor, but they have some differences:

In the rotor, high quality aluminum, reduced fan losses, a greater length, closer machining tolerances, optimized air gap. In the stator, thinner steel laminations, more copper in the windings, higher quality.

On the Fig. 1 is represented the new Efficiency Classes for thee phase induction motors with:

- $\quad$ Rated voltage up to $1,000 \mathrm{~V}$;

- $\quad$ Rated output between $0.75 \mathrm{~kW}$ and $375 \mathrm{~kW}$. Either 2, 4 or 6 poles;

- Rated on the basis of continuous duty (S1) or intermittent periodic duty (S3) with cyclic duration factor of $80 \%$ or higher;

- Capable of operating direct on-line;

- Rated for operating conditions in accordance with IEC 60034-1 (temperature, installation altitude, etc.).

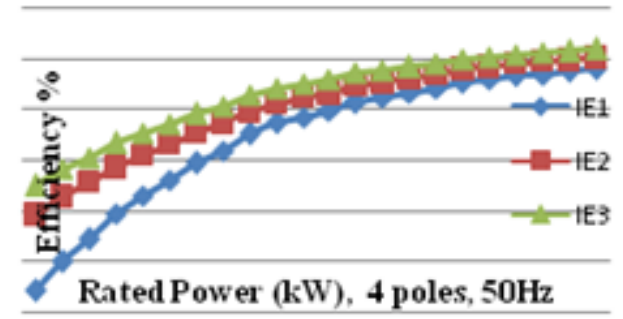

Fig. 1. New Efficiency Classes for thee phase induction motors with $2 p=4$, $\mathrm{f}=50 \mathrm{~Hz}[8]$.

\section{AdVAntages of ENERGy EFFICIENCY Motors}

There are several advantages to energy efficiency motors as:

- Lower energy cost.

- Higher power factor. The amperage draw of the high efficiency motors is lower, and the electrical demand charges are reduced.

- Energy efficiency motors tend to run cooler, as consequence, the life of the motor is expected to be longer.

- Smaller, less expensive power factor correction equipment is needed with energy efficiency motors.

Advantages of energy efficiency motors:

- The productivity is increased

- The energy's cost is decreased.

- The power factor is higher.

- The correction device of power factor is smaller and less expensive

- Lower temperature,

- longer life.

- Reduction of noise,

- lower maintenance costs

- Ability to handle the overload

- Improving the resistance of abnormal operating conditions as under voltage and over voltage, phase unbalance, etc.

- Advantages in application with power supplies coming from inverters

Economic conditions lead to one of these ways:

1. New EEM purchase instead of repairing a faulted standard one.

2. Replacement of an old standard motor with an energy efficiency one.

3. Replacing existing motor with lower energy efficient motor [2].

\section{ENERGY IMPACT OF NEW EFFICIENCY STANDARD}

The influence on the economic evaluation for EEM has energy and power cost $(€ / \mathrm{kWh}$ and $€ / \mathrm{kW})$, rated motor power, rated motor efficiency, load factor and a number of operating hours per year, etc. [7].

Before making investment decisions to evaluate the total economic benefits of a particular drive system, it is important to conduct a life cycle cost (LCC) analysis.

A very simple LCC analysis can be carried out as a component for the motor. The energy costs during the usage phase are significant. 
The annual energy used and the electricity price influence the cost of operation on electric motors. After that the LCC can be calculated.

$$
\text { AnnualSaving }=h P_{n}(L F \%) c\left(\frac{1}{\eta_{s t}}-\frac{1}{\eta_{e m}}\right)
$$

where: $\mathrm{h}$ - annual running time (hours), $\mathrm{P}_{\mathrm{n}}-$ motor rating in $\mathrm{kW}, \mathrm{LF} \%$ - load factor, c- electricity cost in $€ / \mathrm{kWh}$,

$\eta_{\mathrm{st}}$ - efficiency of standard motor, $\eta_{\mathrm{em}}$ - efficiency of energy efficient motor

\section{VARIABLE SPEED DRIVE}

Compressors, pumps and fans are the equipment mostly used even in commercial and residential sectors. In the constructions with constant speed, motors are designed with bigger size because of the overloads that often occur in the system increasing the system's capacity for the future. They rarely operate at their designed load due to safety factors. This leads to a bigger size of the motor.

However, systems in the residential and commercial sectors could get advantages from a variable frequency drive adjusting motor speed that can operate in accordance with the given requirements. The relationship between speed and power for fans, pumps, and compressors, is such that a $10 \%$ reduction in speed generally results in $30 \%$ reduction in power. Therefore, operating fans, pumps or compressors at lower speeds for longer periods can lead to reduced total energy consumption. Operating at a lower, more continuous speed also eliminates other system losses associated with the on/off operation of conventional single-speed systems. In a constant load application, adding a VSD could actually decrease overall efficiency due to inefficiencies in the drive itself. There are relationships of efficiency versus load in a variable speed drive. If the load is less than $25 \%$ of the rated load, the efficiency is lower too. Higher value of efficiency is obtained by a load higher than $25 \%$ of the rated one. In most cases the speed regulation of the ventilator is not required, therefore the motor control is usually an open-loop control with a sensor or sensor less.

\section{BLDC MOTOR}

BLDC Motor (Brushless Direct Current) motor is the DC motor without brushes. Given the name, the most important characteristic is that it is without brushes to transform the DC current into AC current. They are replaced by electronics circuits, consequently they do not have sparks, do not need maintenances that lead to a long life. Thus, the development of this motor shows that it possesses even more positive characteristics if it is compared to the Induction and DC motor. This is the reason why BLDC motors are used in many fields.

BLDC Motors are not like the standard motors. These motor are the result of research not only in the field of motor design but also in other areas such as power electronics, magnetic materials with very good magnetic properties.

They are called Synchronous Motors because the rotor has the same speed as the magnetic field of the stator generated by motor magnetic force (m.m.f) of the stator winding. So, there is no slip between the stator and the rotor field of the BLDC motor.

BLDC motors can be one or three phases. They can be found in many designs, but the most important group are: in runner motors and out runner motors. The in runner motors have the rotor inside the motor. They can produce higher speed with lower torque. Out runner motors are designed with the rotor outside the motor and they enable lower speed with a higher torque.

The changes in the construction that produced a better performance are:

A- the use of permanent magnets created from rare earth materials (Neodymium, Ferrite, Boron). These magnets create strong magnetic field, as a consequence this motor does not need the pole windings that bring less electrical losses, lower volume and weight.

B- the replacement of brushes with electronic circuits to transform the DC current into AC current. No Spark, no noise, no brush consumptions, no maintenances etc. Electrical and mechanical losses are eliminated.

$\mathrm{C}$ - the existence of a feedback between the position of the rotor and the voltage sequences that energize the stator windings. This feedback brings the linear mechanical characteristic, wide range of speed, higher starting torque and possibility of better control.

The detection of the rotor position is made by hall sensor, optical encoder or resolvers or from the sensorless method.

D- the electronic controller creates the possibility of using the advanced control method, sensorless and intelligence that leads to a higher performance of the motor.

The BLDC motor is called the miracle of technology, because of the excellent performance, that comes from its attributes. In the Table II the characteristics of this motor compared to those of the induction and DC motors are listed.

The paper is focused on a three-phase BLDC motor. The formulas used for calculating the losses of three phase BLDC motor are presented at formulas, (2),(3),(4).

$$
\begin{aligned}
P_{C u, s t} & =R_{a}\left(i_{d}^{2}+i_{q}^{2}\right) \\
P_{\text {iron }} & =R_{c}\left(i_{c d}^{2}+i_{c q}^{2}\right) \\
P_{F r, \text { wind }} & =M_{F r} \omega_{M e s h}+B \omega_{M e c h}^{2} \\
& \quad \text { stator copper loss }(\mathrm{P} \mathrm{Cu}, \mathrm{St}) ;- \text { core losses }(\mathrm{P} \quad \text { Iron }), \\
& \text { (hysteresis losses, eddy current losses) } \\
-\quad & \text { friction loss }\left(\mathrm{P}_{\mathrm{Fr}}\right), \\
- & \text { windage loss }\left(\mathrm{P}_{\text {Wind }}\right)
\end{aligned}
$$

Input power is calculated: output power plus the losses.

$P_{\text {in }}=P_{C u, s t}+P_{F e}+P_{F r i, \text { wind }}+P_{o u t}$ 


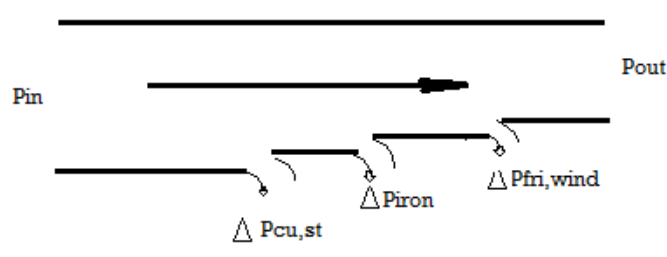

Fig. 2. Power flow diagram of BLDC motor. [6].

Motor efficiency is quantified as equations:

$$
\begin{aligned}
& E f f=\frac{P_{\text {out }}}{P_{\text {in }}} 100 \% \\
& E f f=\frac{P_{\text {in }}-\left(P_{C u, s t}+P_{F e}+P_{F r i, \text { wind }}\right)}{P_{i n}} 100 \% \\
& E f f=\frac{M_{M e c h} \omega_{M e c h}}{P_{i n}} 100 \%
\end{aligned}
$$

As it is seen there are no cupper losses in the rotor of the BLDC motor. The magnetic field of the rotor is created by strong permanent magnets [6].

\begin{tabular}{|c|c|c|c|}
\hline ter & & & (Brushless DC motor) \\
\hline Losses & $\begin{array}{l}\text { Higher losses compared to } \\
\text { DC motor }\end{array}$ & $\begin{array}{l}\text { The losses are lower than } \\
\text { those of the induction } \\
\text { motor. }\end{array}$ & $\begin{array}{l}\text { Lower losses than DC and induction motors } \\
\text { because of elimination of pole winding and } \\
\text { brushes. }\end{array}$ \\
\hline Efficiency & $\begin{array}{l}\text { Lower than DC and BLDC } \\
\text { motors because of higher } \\
\text { losses. }\end{array}$ & $\begin{array}{l}\text { Higher than induction } \\
\text { motors. }\end{array}$ & $\begin{array}{l}\text { Using of the permanent magnet brings the } \\
\text { elimination of pole winding, using of the } \\
\text { inverter brings the elimination of the } \\
\text { brushes, as a consequence of these } \\
\text { decreasing of the losses and increasing the } \\
\text { efficiency. }\end{array}$ \\
\hline Thermal performance & $\begin{array}{l}\text { Thermal performance of } \\
\text { the induction motor is } \\
\text { better than the DC motor's } \\
\text { performance. It is worse } \\
\text { than thermal performance } \\
\text { of the BLDC motor. }\end{array}$ & $\begin{array}{l}\text { Thermal performance of } \\
\text { the DC motor is worse than } \\
\text { performance of the } \\
\text { induction motor and BLDC } \\
\text { motor. }\end{array}$ & $\begin{array}{l}\text { Thermal performance of BLDC motor is } \\
\text { the best. Thermal losses are in the stator } \\
\text { winding and stator core, which in the most } \\
\text { cases is on the outer part of the motor and } \\
\text { the heat can easily go out. }\end{array}$ \\
\hline Overload & $\begin{array}{l}\text { Less overload because of } \\
\text { not good condition of } \\
\text { thermal performance }\end{array}$ & $\begin{array}{l}\text { Less overload because of } \\
\text { not good condition of } \\
\text { thermal performance }\end{array}$ & $\begin{array}{l}\text { Higher ability for overload because of good } \\
\text { thermal performance. }\end{array}$ \\
\hline Dynamic respond & Slower & Slower & $\begin{array}{l}\text { Faster because of lower inertia. (No } \\
\text { brushes, no rotor winding) }\end{array}$ \\
\hline The ratio of power to size & $\begin{array}{l}\text { Moderated } \\
\text { There are windings in the } \\
\text { stator and rotor. }\end{array}$ & $\begin{array}{l}\text { Moderated or low. The size } \\
\text { and weight lower than the } \\
\text { induction motor with the } \\
\text { same power. }\end{array}$ & $\begin{array}{l}\text { Higher. There are only stator winding, } \\
\text { small size than DC and induction motor for } \\
\text { the same power. }\end{array}$ \\
\hline Environmental pollution & Low noise & $\begin{array}{l}\text { Noise because of the } \\
\text { brushes and interference } \\
\text { RFI (Radio Frequency } \\
\text { interference), sparks etc. }\end{array}$ & $\begin{array}{l}\text { BLDC motor is cleaner than both motors. } \\
\text { Saving of materials copper, iron, brushes, } \\
\text { and smaller size. } \\
\text { Reduce the electromagnetic interference } \\
\text { (EMI) Lower interference RFI ( radio } \\
\text { frequency interference), no noise because } \\
\text { of elimination of brushes }\end{array}$ \\
\hline Long life & $\begin{array}{l}\text { The life of the induction } \\
\text { motor is longer than the life } \\
\text { of the DC motor. }\end{array}$ & $\begin{array}{l}\text { The life of the DC motor is } \\
\text { shorter than the induction } \\
\text { motor life because of } \\
\text { brushes consume. }\end{array}$ & $\begin{array}{l}\text { Long life, total working hours are much } \\
\text { more than the DC motors. It does not need } \\
\text { maintenance. }\end{array}$ \\
\hline Technology & $\begin{array}{l}\text { Production technology of } \\
\text { the IM motors essentially is } \\
\text { the same as it was many } \\
\text { years ago. }\end{array}$ & $\begin{array}{l}\text { The same technology is } \\
\text { used for production of the } \\
\text { DC motors, as it was many } \\
\text { years ago, but the control } \\
\text { schemas are improved. }\end{array}$ & $\begin{array}{l}\text { Production technology of the BLDC motors } \\
\text { is quite new, based on qualitative materials } \\
\text { for permanent magnets, electronic circuits } \\
\text { for supply and control. }\end{array}$ \\
\hline Costs & Low & High & $\begin{array}{l}\text { Cost is gradually relatively decreased. Cost } \\
\text { is higher than the DC motor. }\end{array}$ \\
\hline
\end{tabular}

TABLE II: COMPARING SOME Characteristics OF THE INDUCTION MOTOR, DC AND BLDC Motors FOR THe SAME Power [1],[3],[4],[7]-[12] Characteristics $\quad$ Induction motor $\quad$ DC motor $\quad$ BLDC Motor

Application
Noise and ripple of the torque limit the applications. This motor is used where it is needed the regulation of the speed and the energy source is AC.
This motor is used, of course where the energy source is DC. Low power DC motors are used in automation, in control systems etc. In other fields it is limited, only when it is needed high starting torque.
BLDC motors are used in many applications, for example in electric and hybrid vehicles, aerospace, household appliances, industry, robotics, military, medicine, etc. In those applications weight and volume are important. BLDC motors are supplied with AC or DC voltage but associated with appropriated circuits. 


\section{MATERIALS AND METHODS}

This case study is based on [6], where we highlight the experimental data comparing efficiency between a shaded pole single-phase induction motor fan application and a three-phase BLDC motor application. The power of both motors are less than $100 \mathrm{~W}$.

The same fan is driven by shaded-pole single-phase induction motor and after that by three-phase BLDC motor.

\section{A. Analytic Process}

The efficiency of the motor is calculated as the ratio of the output power with the input power. The formulas are given:

$$
\eta_{I M}=\frac{P_{o u t, I M}}{P_{i n, I M}} 100 \% \quad \eta_{B L D C}=\frac{P_{o u t, B L D C}}{P_{i n, B L D C}} 100 \%
$$

If it is assured the same output power for both motors, then the motor which consumes the lower input power has the higher efficiency.

The steps to be followed: a) to assure the same output power for both motors, b) to measure the input power for both motors, c) to compare the input power of both motors for the same speed, d) to calculate the saving energy when it is replaced the IM motor with the BLDC motor.

$\mathrm{P}_{\text {out,IM }}=\mathrm{P}_{\text {out,BLDC }}$. As it is known, the operating point of an electrical transmission is defined by cutting point of the mechanical characteristic of the electrical motor and the mechanism, (in this case the fan). The mechanical torque of the fan is a function of the mechanical speed which is given by a parabolic curve as it is shown on the Fig. 3. The power required to drive the fan with a specific speed and correspondent torque is calculated as:

$$
\begin{aligned}
& M \equiv n^{2} \\
& P_{\text {out }}=M \omega=M \frac{2 \pi n}{60}=\frac{M n}{9.55}
\end{aligned}
$$

where:

$$
\begin{aligned}
& \mathrm{n} \text {-speed }(\mathrm{RPM}) \\
& \omega \text { - angular velocity (rad./s) } \\
& \mathrm{M} \text { - load static torque }(\mathrm{Nm}) \\
& \mathrm{P} \text { - power }(\mathrm{W})
\end{aligned}
$$

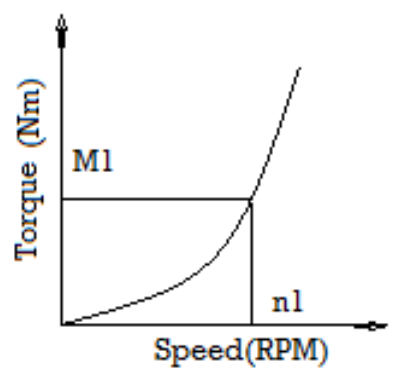

Fig. 3. Torque as a function of speed
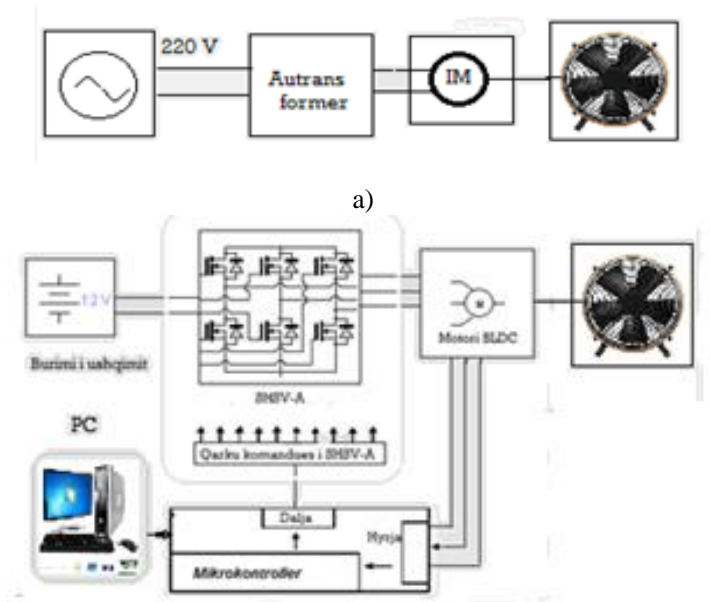

b)

Fig. 4. a) The block diagram of the IM, b) The block diagram of the BLDC motor

If the motors are rotated with the same speed, and if it is used the same fan blades then the load torque defined by the mechanical curve of the fan is the same. The same speed of rotation with the same fan blades for both motors means the same output power. $P_{\text {out }, I M}=P_{\text {out }, B L D C}$

The shaded pole single-phase IM speed was with autotransformer changed, whereas the BLDC motor speed was varied electronically. The block schemas are given on the Fig. 4.

Indirect measurement of input power for both motors when they drive the same ventilator with the same speed.

For different speeds, it is measured the input voltage, current and power factor for the induction motor. The input power is calculated:

$P_{i n, I M}=V_{i n} I_{i n} \cos \varphi$

The results are put in the Table III.

For different speeds, it is measured the input voltage, current for the BLDC motor. The input power is calculated

$$
P_{i n, B L D C}=V_{i n} I_{i n}
$$

The results are put in the Table IV.

The volume of BLDC motor is about 2 times smaller than induction motor so the BLDC power density is higher compared to that of the induction motor. The BLDC motor is supplied by $11.1 \mathrm{~V}$ battery and the induction motor is supplied by $220 \mathrm{~V}$ from the power system. [6],[11]-[13] It is not presented the exact operating point in terms of torque and speed.

On the Fig. 5 is presented the experiment place, and on the Fig. 6, the components of BLDC motor. 


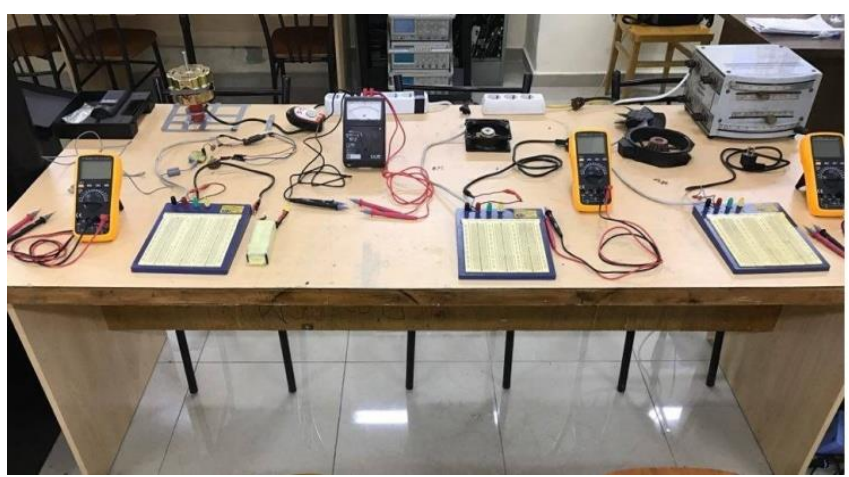

Fig. 5. Experiments place

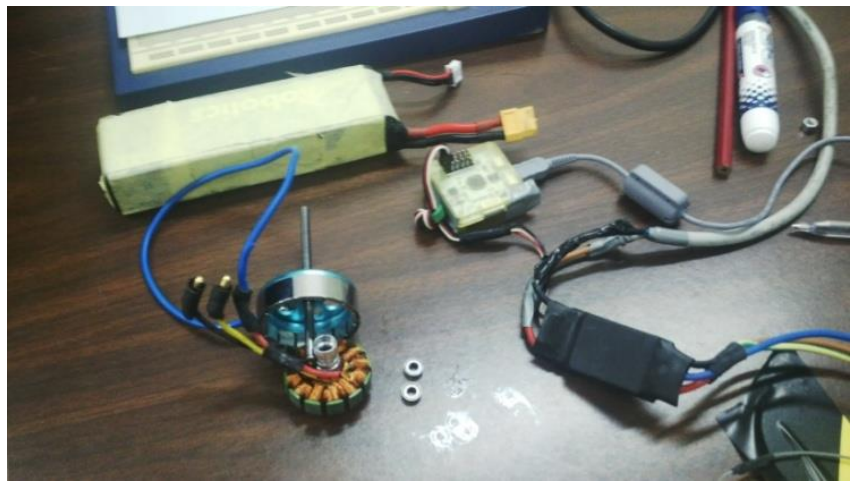

Fig. 6. The components of BLDC motors

B. Equipment used in the Experiment

a. Ventilator Tip: Papst Typ4650N TYP 4650N 4221546 230V 19W HIG

b. One phase Induction motor: Papst-Motoren; Typ $4650 \mathrm{~N} ; 230 \mathrm{~V} / 50 \mathrm{~Hz}, 19 \mathrm{~W}$

c. Three- phase BLDC motor: TYP.HK; DT700

Brushless Outrunner 700kv, 11.1V

d. Digital multi meter

e. electronic tachometer

f. autotransformer

g. oscilloscope.

\section{Data from the Experiment}

All the data from experiments are put in the Tables III, IV. Table V is the summary of the Table III and IV. The input power versus speed for both motors are shown on the Fig. 7. In Table $\mathrm{V}$, the input powers of both motors are compared and their ratio is calculated. In the Table VI, the energy consumed for both motors is calculated for a normal work of 4 hours per day in one year, and the energy savings by replacing induction motor with BLDC motor they are represented on the Fig. 8.

TABLE III: Voltage, CURRENT, POWER, POWER FACTOR OF INDUCTION MOTOR

\begin{tabular}{ccccccc}
\hline \hline No & \multicolumn{2}{c}{ Measured quantities } \\
& & $\begin{array}{c}\text { Input } \\
\text { voltage } \\
\mathrm{V}_{1} \\
(\mathrm{~V})\end{array}$ & $\begin{array}{c}\text { Input } \\
\text { current } \mathrm{I}_{1} \\
(\mathrm{~mA})\end{array}$ & $\begin{array}{c}\text { Power } \\
\text { factor }\end{array}$ & $\begin{array}{c}\text { Apparent } \\
\text { Power } \\
\mathrm{S}_{1}=\mathrm{V}_{1} \mathrm{I}_{1} \\
(\mathrm{VA})\end{array}$ & $\begin{array}{c}\text { Active } \\
\text { Power } \\
\mathrm{P}_{1}=\mathrm{S}_{1} * \\
\cos (\varphi) \\
(\mathrm{W})\end{array}$ \\
\hline & & & & & & \\
1 & 1424 & 147.3 & 78.3 & 0.86 & 11.53 & 9.92 \\
2 & 1505 & 150.0 & 79.5 & 0.86 & 11.93 & 10.26 \\
3 & 2172 & 179.8 & 92.8 & 0.86 & 16.69 & 14.35 \\
4 & 2344 & 200.0 & 104.0 & 0.86 & 20.80 & 17.89 \\
\hline \hline
\end{tabular}

TABlE IV: Voltage, CurRent, POWER, POWER FACTOR OF THREE PHASE BLDC MOTOR

\begin{tabular}{ccccccc}
\multicolumn{7}{c}{ PHASE BLDC MOTOR } \\
\hline \multicolumn{7}{c}{ Measured quantities } \\
$\mathrm{N}$ & $\begin{array}{c}\text { Rotation } \\
\text { (RPM) }\end{array}$ & $\begin{array}{c}\text { Input } \\
\text { voltage } \\
\mathrm{V}_{1} \\
(\mathrm{~V})\end{array}$ & $\begin{array}{c}\text { Input current } \\
\mathrm{I}_{1} \\
(\mathrm{~mA})\end{array}$ & $\begin{array}{c}\text { Power } \\
\text { factor } \\
\cos (\varphi)\end{array}$ & $\begin{array}{c}\text { Apparent } \\
\text { Power } \\
\mathrm{S}_{1}=\mathrm{V}_{1} * \mathrm{I}_{1} \\
(\mathrm{VA})\end{array}$ & $\begin{array}{c}\text { Active } \\
\text { Power } \\
\mathrm{P}_{1}=\mathrm{S}_{1} * \\
\cos (\varphi) \\
(\mathrm{W})\end{array}$ \\
& & & & & & \\
\hline & & & & & & \\
1 & 1424 & 12.43 & 242 & $\approx 1$ & 3.01 & 3.01 \\
2 & 1505 & 12.42 & 259 & $\approx 1$ & 3.22 & 3.22 \\
3 & 2172 & 12.37 & 442 & $\approx 1$ & 5.47 & 5.47 \\
4 & 2344 & 12.34 & 526 & $\approx 1$ & 6.49 & 6.49 \\
\hline
\end{tabular}

TABLE V: COMPARISON OF POWER CONSUMPTION BY INDUCTION MOTOR AND BLDC MOTOR IN FAN APPLICATION

\begin{tabular}{ccccc}
\hline \hline $\mathrm{Nr}$ & $\begin{array}{c}\text { Speed } \\
(\mathrm{RPM})\end{array}$ & $\begin{array}{c}\text { Power } \\
(\mathrm{W})\end{array}$ & $\begin{array}{c}\text { Power } \mathrm{P}_{\text {BLDCl }} \\
(\mathrm{W})\end{array}$ & $\begin{array}{c}\text { Ratio of Power } \\
\mathrm{P}_{\text {IIM }} / \text { PIBLDC }\end{array}$ \\
\hline 1 & 1424 & 9.92 & 3.01 & 3.296 \\
2 & 1505 & 10.26 & 3.22 & 3.19 \\
3 & 2172 & 14.35 & 5.47 & 2.62 \\
4 & 2344 & 17.89 & 6.49 & 2.75 \\
\hline \hline
\end{tabular}

TABLE VI: COMPARISON OF ANNUAL ENERGY CONSUMPTION FOR ONE YEAR

\begin{tabular}{ccccccc}
\multicolumn{8}{c}{ YEAR } \\
\hline \hline No & $\begin{array}{c}\text { Speed } \\
(\text { RPM })\end{array}$ & $\begin{array}{c}\text { Power } \\
\mathrm{P}_{1} \\
(\mathrm{~W})\end{array}$ & $\begin{array}{c}\text { Annual } \\
\text { Energy } \\
\text { consumption } \\
(\mathrm{kWh})\end{array}$ & $\begin{array}{c}\text { Power } \\
\mathrm{P}_{1} \\
(\mathrm{~W})\end{array}$ & $\begin{array}{c}\text { Annual } \\
\text { Energy } \\
\text { consumpti } \\
\text { on }(\mathrm{kWh})\end{array}$ & $\begin{array}{c}\text { Annual } \\
\text { Energy } \\
\text { Savings } \\
(\mathrm{kWh})\end{array}$ \\
\hline & & & & & & \\
& & & & & & \\
1 & 1424 & 9.92 & 14.48 & 3.01 & 4.39 & 10.09 \\
2 & 1505 & 10.26 & 14.98 & 3.22 & 4.70 & 10.28 \\
3 & 2172 & 14.35 & 20.95 & 5.47 & 7.98 & 12.97 \\
4 & 2344 & 17.89 & 26.12 & 6.49 & 9.47 & 16.65 \\
\hline \hline
\end{tabular}

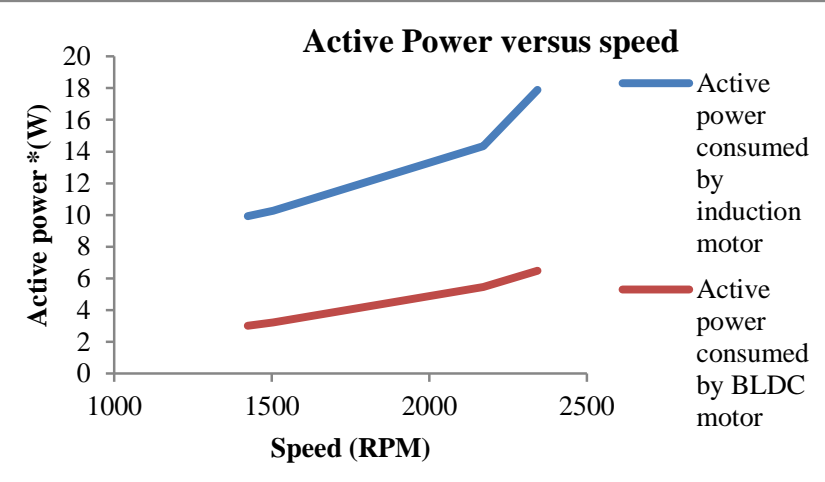

Fig. 7. Active power versus speed for induction motor and BLDC motor driving a fan

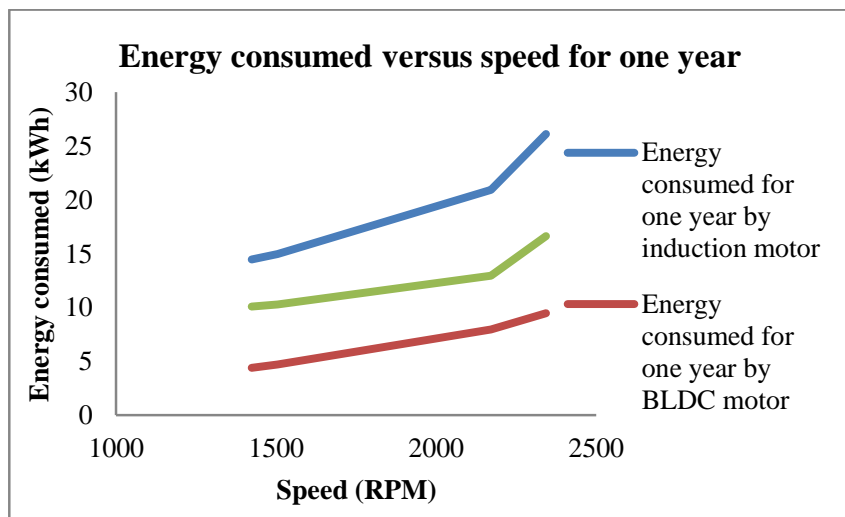

Fig. 8. Energy consumed from induction motor and BLDC motor, energy saving when the induction motor is replaced with the BLDC motor driving a fan for one year. 


\section{RESULTS AND CONCLUSIONS}

Measuring the input power of an induction motor and a BLDC motor driving a ventilator results in:

1. The BLDC motor consumes less energy than the shaded-pole single-phase induction motor. The ratio of power consume, between induction motor and BLDC motor for a same speed is on average 3 times more.

2. The energy saving when the induction motor is replaced with a BLDC motor driving a ventilator for 4 hours in a day for one year, is from 10.09 $\mathrm{kWh} \div 16.65 \mathrm{kWh}$, calculated for a different number of rotations. Since the number of such ventilators is high, the saving of electrical energy must be taken in consideration.

Saving of electrical energy when driving the fan is ensured by replacing the shaded-pole single-phase induction motor with BLDC motor. This replacement brings even more advantages such as no noise, no maintenance, low volume and weight, etc. Especially this is important in applications with variable speed drives because of fast dynamic respond, less waiting time etc. The conclusions are in accordance with the recommendations of literature.

In the industrial and residential sectors, the main use of energy is the conversion of electromechanical energy. This conversion is usually done by electric motors. If it is used an efficient form of the conversion of the energy, then it reduces the cost of energy and the impact in the environment. The induction motor was for a long time a favorable solution compared to ceramic magnet motors that were not a cost effective solution to generate a strong magnetic field for energy conversion. But advancement in magnetic materials creates the conditions for designing a new, cost-effective motor such as BDC motors. They have shown to offer a better efficiency compared to single-phase induction motors.

This document provides through the experiment that the BLDC motor is more efficient compared to the shaded-pole single-phase induction motor. The data show that BLDC motor can improve efficiency 3.5 times more than a singlephase induction motor. [11]. This approach is helpful as the general BLDC motor systems will be compact and lighter.

These concussions are in accordance with the guidelines provided from the government for motor system efficiency and performance criterion. The usage of BLDC motor instead of induction motor is superior in terms of performance and efficiency.

\section{REFERENCES}

[1] J.E. Miller, Brushless Permanent Magnet and Reluctance Motor Drives, Oxford University Press, 1989, ch 1-3, pp. 2-55.

[2] A. Spahiu, P. Marango, and O. Zavalani, "High efficiency electric drive," Revistë Shkencore e Institutit Alb-Shkenca, AKTET 260, vol. 3, nr 2, pp. 257- 260, 2009.
[3] Ch.-L. Xia, Permanent Magnet Brushless DC Motor Drivesnand Controls, John Wiley \& Sons Singapore, 2012, ch 1,2,8, pp. 1, 3-8, 255-277.

[4] Handbook of electric motors, 2nd ed. Taylor \& Francis Group, LLC, H.A. Toliyat and G. B. Kliman, 2004, ch.15, pp. 763-771.

[5] H. Hembach, Systematischer Vergleich von BLDC-Motor konzepten mit Anwendung auf nass laufende Wasser pumpen kleiner Leistung, Ph.D. dissertation, Fakultät für Elektrotechnik und Informationstechnik, Universität der Bundeswehr München, 2007, pp. $2-10$.

[6] S. S. Kuruppu, and J. K. Rote. (April 2016). Replacing single-phase ACIMs with three-phase BLDC motors saves energy. Texas Instruments [Online]. pp. 2- 3,7-8,11-12, 16. Available: http://www.ti.com/lit/wp/slyy083/slyy083.pdf.

[7] BLDC motor. (February 2016). The Power of Brushless DC Motors Oriental motor New Motion Newsletter, Oriental Motor USA Corp, [Online]. pp.3-5. Available: http://www.orientalmotor.com/technology/articles/brushless-dcmotors-servo-motors-inverters.html.

[8] P. Waide, and C. U. Brunner. (2011). Energy-Efficiency Policy Opportunities for Electric Motor-Driven Systems. International Energy Agency OECD/IEA. [Online]. pp.11- 13,18,23,33, 2011. Available: htpp://www.iea.org.

[9] BLDC motor. (May 2017). New trends in electric motors: Efficiency, power density, torque. Motion and control tips, a design world resource. BISON, Gear \& Engineering Corp.1-800-AT-Bison. [Online]. Retrieved from: http://www.motioncontroltips.com/electricmotors-higher-and- higher- and-higher.

[10] G. Feng, W. Qi, B. Zhang and Ch. Li, "Analysis and comparison of three-phase variable frequency PMSM with single-phase induction motor in household appliances," presented at the International Conference of Electrical Machines and Systems (ICEMS), 2011, Aug. 20- 23, 2011.

[11] A.T. De Almeida, F.J.T.E. Ferreira and J.A.C. Fong, "Standards for Efficiency of Electric Motors," Industry Applications Magazine, IEEE, vol.17, no.1, pp. 12-19, Jan.-Feb. 2011.

[12] J. Dalvi. (Oktober 2015). "24-V,50W BLDC Motor Sinusoidal Drive for Air Purifier Fans," TI Designs. [Online]. pp.1-13. Available: http://www.ti.com/lit/ug/tiduaj0a/tiduaj0a.pdf

[13] S. Vaez-Zadeh and B. Zahedi, "A Steady State Model Including Iron loss for Variable Speed Single-Phase Induction Motors," presented at Power Electronics Specialists Conference, 2007. PESC 2007, IEEE. June 17-21, 2007.

[14] Fletore Zyrtare Nr.214, "Per miratimin e planit te II dhe te III kombetar te veprimit per eficencen e energjise per Shqiperine 2017 2020", VKM 709, date 01.12.2017, pp.11183- 11193. Official Journal No.214, "On the Approval of the Plan II and III national energy efficiency action for Albania 2017- 2020,"VKM 709, 01.12.2017, pp.11183- 11193.

Loreta Nakuçi graduated at the Faculty of Electrical Engineering at the Polytechnic University Tirana in 1984. She has worked as a teacher of professional subjects at the Harry Fultz Institute, as head of electricalelectronic departments at Harry Fultz Institute, and since 2004 until now as Vice director at Harry Fultz Institute.

In the 2012 she started the doctoral school at the Polytechnic University of Tirana. Since 2013 she has worked part time seminars and lecture of the subject "Introduction in the circuits analyses". Her focus now is the research on BLDC motors' drives.

Aida SPAHIU graduated at the Faculty of Electrical Engineering at Polytechnic University of Tirana in 1989. She holds a PhD diploma in Electrical Engineering from 2004 and she worked in all didactic positions since 1989 when she joined the staff of the Faculty of Electrical Engineering, assistant lecturer in 1989, senior lecturer in 1997, associate professor in 2012 and full professor in 2016.

Currently she is full Professor of Electrical Drives in the Department of Automation, head of research group of "Electrical Machines and Drives" and head of Department of Automation. She is the author of 1 book and over 25 articles in the field of control of variable speed drives. Her work focuses on the energy efficiency of electrical drives, fuzzy logic based and sliding mode control, sensorless control of electric drives. 